University of Nebraska - Lincoln

DigitalCommons@University of Nebraska - Lincoln

July 1967

\title{
Effects of Dietary Safflower Oil or Hydrogenated Coconut Oil on Growth Rate and on Some Blood and Tissue Components of Pigs fed a Fat-free Diet
}

G. M. Babatunde

New York State College, Ithaca

W. G. Pond

New York State College, Ithaca

L. Krook

New York State College, Ithaca

L. Dale Van Vleck

University of Nebraska-Lincoln, dvan-vleck1@unl.edu

E. F. Walker Jr.

New York State College, Ithaca

See next page for additional authors

Follow this and additional works at: https://digitalcommons.unl.edu/animalscifacpub

Part of the Animal Sciences Commons

Babatunde, G. M.; Pond, W. G.; Krook, L.; Van Vleck, L. Dale; Walker, E. F. Jr.; and Chapman, P., "Effects of Dietary Safflower Oil or Hydrogenated Coconut Oil on Growth Rate and on Some Blood and Tissue Components of Pigs fed a Fat-free Diet" (1967). Faculty Papers and Publications in Animal Science. 174. https://digitalcommons.unl.edu/animalscifacpub/174

This Article is brought to you for free and open access by the Animal Science Department at DigitalCommons@University of Nebraska - Lincoln. It has been accepted for inclusion in Faculty Papers and Publications in Animal Science by an authorized administrator of DigitalCommons@University of Nebraska - Lincoln. 


\section{Authors}

G. M. Babatunde, W. G. Pond, L. Krook, L. Dale Van Vleck, E. F. Walker Jr., and P. Chapman 
From The Journal of Nutrition Authors' Statement and Copyright Release Form (p. 3):

e. Authors may post a link on a personal website that directs readers to the article on The Journal of Nutrition website (www.jn.nutrition.org); full text of the final, published article can not be posted on personal or institutional websites or repositories that are accessible to the public.

\title{
Effects of Dietary Safflower Oil or Hydrogenated Coconut Oil on Growth Rate and on Some Blood and Tissue Components of Pigs fed a Fat-free Diet
}

\author{
G. M. Babatunde, W. G. Pond, L. Krook, L. D. Van Vleck, E. F. Walker, Jr., \\ and P. Chapman
}

Department of Animal Science, New York State College of Agriculture and New York State College of Veterinary Medicine, Cornell University, Ithaca, New York

The effects of feeding diets containing no fat, 3\% hydrogenated coconut oil (HCO) or graded levels $(0.1,0.5,1.0$ or $3 \%$ ) of safflower oil (SO) on serum cholesterol, lipids and protein level; on total heart and liver cholesterol and lipid level and on growth rate and skin condition were studied in weanling Yorkshire and Yorkshire $x$ Hampshire pigs. Pigs fed the fat-free diet for 21 weeks developed severe skin lesions not observed in pigs fed HCO diets. Highly significant elevation of serum, liver and heart lipid and liver cholesterol, and a highly significant depression of total serum protein were observed with the feeding of HCO or fat-free diets. Serum cholestrol was significantly increased by HCO as compared with the fat-free diet or diets containing SO during the repletion period. Total heart cholesterol, growth rate and erythrocyte fragility were unaffected by diets. It is concluded that growth rate is not adversely affected in the pig by fat-free diets and that HCO does not produce skin lesions in the pig characteristic of fatty acid deficiency. Of all the correlation coefficients analyzed, only the serum cholesterol and total serum lipids were consistently highly significantly correlated, while serum protein was significantly inversely related to the total liver lipid.

Manuscript submitted January 20, 1967.

Published in Journal of Nutrition Vol. 92 No. 3 July 1967, pp. 293-302

Copyright (C) 1967 by American Society for Nutrition.

Online at: http://jn.nutrition.org/cgi/reprint/92/3/293 